\title{
Chapter 2. The Origin Structure of Kute Among the Gumai: An Analysis of an Indigenous Territorial Institution in the Highlands of South Sumatra
}

\author{
Minako Sakai
}

This chapter examines indigenous territorial categories in the highlands of the Province of South Sumatra, by focusing on Gumai villages. While desa is the official term for villages, conceived as administrative units of the modern Indonesian State, and while most people will name their dusun or 'hamlet' when asked about their place of residence, local ritual specialists still use kute as the traditional term to refer to a residential territory (from Sanskrit and Old-Malay kuta, 'fortified town' or 'palace'). They do so primarily in the context of the rituals to commemorate the origin of the kute.

The Gumai are a Malay-speaking people who reside in the highlands of South Sumatra (Jaspan 1976). Their population across three major residential areas in the Regency of Lahat is approximately 10,000 people, who derive their livelihood largely from the cultivation of rubber and coffee. In terms of language, appearance and customs, the Gumai have much in common with neighbouring Malay speakers. Historically, South Sumatran highland societies consisted of groups who defined themselves by descent from common ancestors and by reference to the specific area of land they inhabited (Andaya 1993: 17). The distinctive identity of the Gumai, for example, derives from the belief that their people are all the offspring of a magical founding ancestor, Diwe Gumai, who descended on Mt Segungtan in Palembang on the night of a full moon (Sakai 1997 and 1999). The descendants of Diwe Gumai then spread along the river system, known as Batang Hari Sembilan, which flows across the region and founded numerous villages. Relocation of some of these villages took place at the turn of the last century in accordance with the replacement of the river system as the main means of transportation by a network of roads.

Presently, most villages in the South Sumatran highlands are located neatly along the main roads. There are three main clusters of villages, all in the Regency of Lahat, namely Gumai Ulu, Gumai Lembak and Gumai Talang. Jurai Kebali'an is a title carried by a male heir who represents the most authentic successor of the founding ancestor in terms of genealogical connections. The house of the Jurai Kebali'an is located in the regency of Lahat of South Sumatra Province, and serves as a most important ritual place to commemorate the common origins 
of the Gumai in a ritual attracting hundreds of Diwe Gumai's descendants every month (see Sakai 2003).

\section{Map 1: Ethnic groups in South Sumatra province}

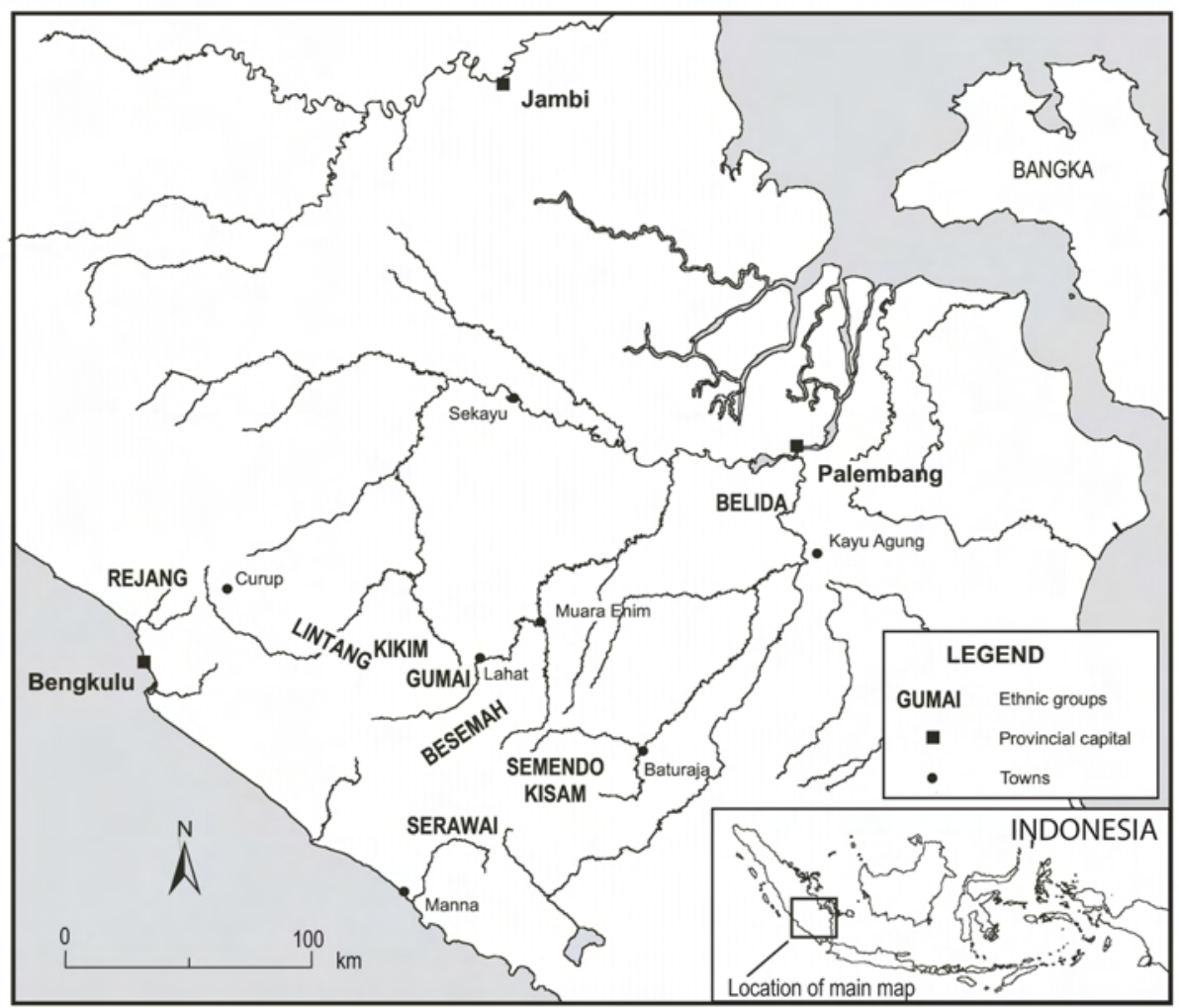

A knowledge of village origins is most important for understanding social structures and associated ritual practices among the Gumai, as well as other Malay-speaking highlanders in South Sumatra. I will therefore begin by examining some village origin stories, collected from settlements in the Gumai Talang region. Gumai Talang consists of 14 villages along the Trans-Sumatra Highway near the town of Lahat. I will show how the village origins are reflected in social and ritual structures. I will then show how Gumai ritual and social practices have contributed to the maintenance of links to a common origin. As a result, Gumai traditional villages, particularly a ritual unit known as kute, have maintained themselves as an indigenous territorial category, based on common origins, despite intervening government administrative policies and frequent relocations of villages. 


\section{Village Origin Structure}

Many Gumai villages are thought to have been established by a single ancestor, the Puyang Ketunggalan Dusun (the Founding Ancestor of the Village), and have been inhabited by his descendants and their affines. Narratives I obtained about the origin of Mandi Angin village from the ritual specialist of Mandi Angin in 1994 are a good example to illustrate the importance of a single village founder as the ultimate origin point, and to show the subsequent process of subgroup formation in this village.

\section{Figure 1: Genealogy of Mandi Angin village}

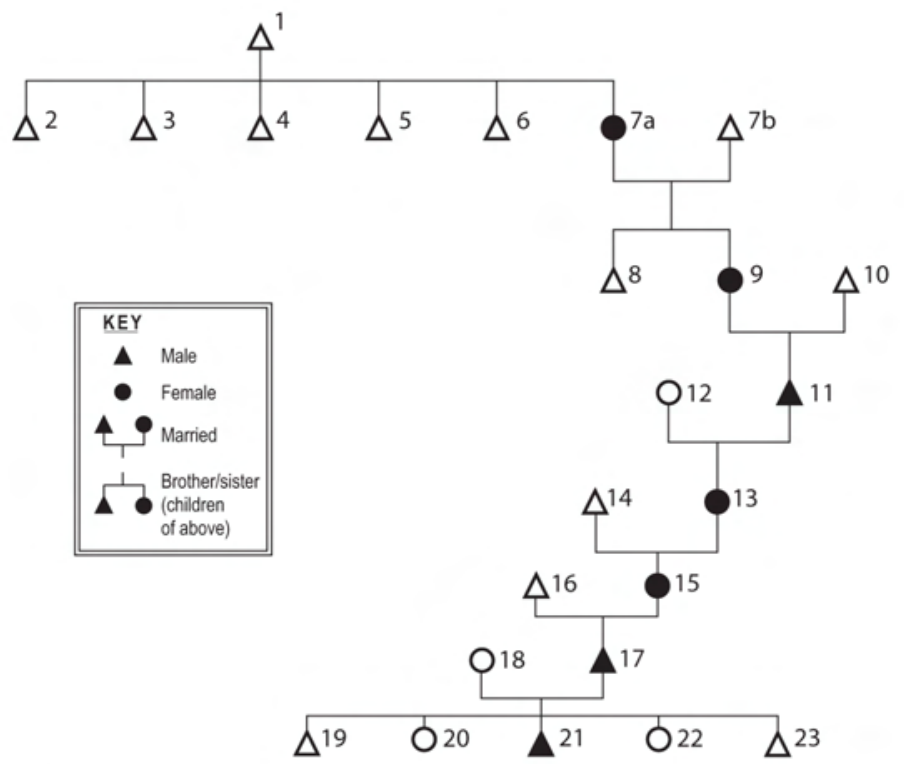

\footnotetext{
1 Puyang Kerie Tingal (Puyang Ketunggalan Dusun) 13 Majenon

2 Raje Ringkeh (Tue Jurai)

14 Raden Ali from Muara Cawan, Kikim

3 Raje Kuhus

15 Retipa

4 Raja Dali

16 Perajin from Ngalam Baru

5 Raje Bungkuk

17 Nagajin

6 Pengiran

18 Name unknown

7a Rebiah (Jurai Tue)

19 Kosim

7b Name unknown (from OganUlu)

20 Name unknown (living in Tebing Tinggi)

8 Artanan

9 Yamani

21 Mimha (living in Mandi Angin), current Jurai Tue in Mandi Angin

10 Name unknown (from Mandi Angin)

22 Siti Robia (living in Tanjung Karangan, Lampung)

11 Tikus Kuning

23 lbrahim (living in Mandi Angin)

12 Sudiya from Mandi Angin
}

Note: Black indicates the succession order of the Jurai Tue. 
The founding ancestor of Mandi Angin village, Puyang Kerie Tingal, was the eldest son of Puyang Gune Raje, who was the Jurai Kebali'an in Lahat. Kerie Tingal had five sons, Raje Ringkeh, Raje Kuhus, Dali, Pengiran and Raje Bungkuk in that birth order. The youngest [child] was a daughter called Rebiah.

Subgroups in Mandi Angin village are known as jungkuk ('subgroup') and derive from each of these six children. Each jungkuk is responsible for passing on the title Jungkuk to one of its members. The appointee needs to reside in his/her villages, to maintain the genealogical knowledge about the ancestors of his/her jungkuk and to undertake rituals to remember those ancestors. Jungkuk refers to a subgroup formed by the children of the founding ancestor and the family or the person who inherits this role. To differentiate these two, I will refer to the subgroup as jungkuk and the title as the Jungkuk title. ${ }^{1}$

Each jungkuk of Mandi Angin village takes its derivation from the ultimate origin point of the village, Puyang Kerie Tingal, the Puyang Ketunggalan Dusun. Figure 1 shows the succession of the jungkuk of the Jurai Tue of Mandi Angin village. The main task of the person with the title of Jungkuk is to reside in his or her native village and to have offspring to continue the genealogical linkage to the village founder. The office needs to be carried on by a successor, who remains in his or her natal village. The succession of this title is through a daughter or a son, and birth order is irrelevant. Currently there are six people, each of whom represents a jungkuk in Mandi Angin village. The successor to the Jungkuk title is assumed to be the closest living descendant of the founding jungkuk ancestor. All the Jungkuk titleholders and other jungkuk members are expected to undertake a series of rituals to commemorate its origins. ${ }^{2}$

\section{Precedence and Village Ritual Specialists}

Despite the fact that each jungkuk has derived from a common ancestor, the status of jungkuk is not equal. One of the jungkuk carries the title of Tue Jurai (elderly subgroup) and another holds the title of Jurai Tue. The notion of jurai is elusive and hazy; it refers to a particular person as a holder of such titles as Jurai Tue, Tue Jurai and Jurai Kebali'an. On the other hand, jurai refers to any number of people who trace their origin to particular ancestors who in turn share a common ancestry in the distant mythological past. The idiom putus jurai means the 'severing or disappearance of legitimate successors'; it does not mean the extinction of an ethnic group. ${ }^{3}$

The following account from Mandi Angin village, which I obtained during my fieldwork in the mid-1990s, will illustrate how jungkuk are differentiated based on birth order and ritual seniority. 
The jungkuk of Raje Ringkeh, the eldest son of the founding ancestor, is paid homage. It is because he is the eldest child of the family and his jungkuk is called Tue Jurai. After growing up, all the male children of Kerie Tingal wanted to leave their natal village and to go to new places. Therefore, Rebiah, the youngest daughter, was asked to remain in the village permanently and took over the house of her parents as the place to which other descendants could return. She was given the title of Jurai Tue, which enabled her to become the village ritual specialist. At the time of the village ritual known as Sedekah Rame, the Jurai Tue invokes ancestral spirits including the Puyang Ketunggalan Dusun. This duty of the Jurai Tue includes keeping the knowledge about genealogies traced to the founding ancestor and having offspring in order to transmit this knowledge. Her husband acted as the caretaker of the village and was called Jurai Tue, as women were not allowed to perform this role. Since then, the title of Jurai Tue has also been inherited among the members of the jungkuk of Rebiah, and the current Jurai Tue remains in Mandi Angin village.

This account explains the way some jungkuk are ranked higher than others. Based on his position as the firstborn, the jungkuk which was headed by Raje Ringkeh is ranked higher than the others and is called Tue Jurai or 'elder descendant group'. The eldest child is seen as temporally closer to the village founding ancestor and is therefore paid homage by the other jungkuk members. ${ }^{4}$ People express respect to the descendants of Tue Jurai. In the past, at the ritual to commemorate the village origins known as Sedekah Rame, the seating arrangements and the nature of the offerings to be prepared were determined by the status and titles of each jungkuk. ${ }^{5}$ Traditionally, however, no political or economic prerogative is given to the Tue Jurai or Jurai Tue. ${ }^{6}$

The account also shows how the jungkuk of Rebiah was chosen as the successor line of the village ritual specialist, Jurai Tue. Since none of the male children stayed permanently within their natal village, the last-born daughter was asked to remain there and to attend to the Gumai customs. In the past, it was customary to allow a daughter to inherit the office of the Jurai Tue and let her husband perform the role. ${ }^{7}$

The Jurai Tue is to reside in the village and to keep knowledge of genealogies that connect the Jurai Tue with the Puyang Ketunggalan Dusun. If there are any regalia handed down from the Puyang Ketunggalan Dusun, the Jurai Tue is responsible for looking after them. ${ }^{8}$ The Jurai Tue is regarded as the most direct descendant of the village founder, and his or her jungkuk as a group is believed to be the closest to the Puyang Ketunggalan Dusun as the ultimate origin point.

The title of Jurai Tue is associated not only with the person who inherits the title, but with the village location in which he or she is designated to live. Outside 
the boundaries of that village, that person can no longer act as the Jurai Tue or bear the office of the Jurai Tue, but is considered an ordinary individual.

When no member of the jungkuk of the Jurai Tue is considered suitable for the office, it can be transferred temporarily to a member of another jungkuk. Since jungkuk titleholders are considered close to the village founder, temporary transfer of the title of Jurai Tue to another jungkuk titleholder is considered appropriate. This custom of temporary transfer is known as menyandung (temporary transfer), and whenever there is an appropriate successor among the members of the jungkuk of the Jurai Tue, the office should be returned.

Figure 2 presents the genealogy of the two Jungkuk of Tanjung Karangan village, who share in rotation the office of Jurai Tue. When Puyang Pageran died, Senang Irah succeeded to the office of the Jurai Tue, and her husband, Setiarap, performed the role. The title of Jungkuk was then transferred (menyandung) to Lamit, a nephew of Senang Irah. ${ }^{9}$ Since Lamit was busy with gardening, the office was transferred to Resek, Lamit's sister. Thereafter, the office was transferred to a daughter of Lamit, Sari, and performed by her husband, Dahlan. Since Dahlan often left the village for work, the office was eventually returned to a grandchild of Senang Irah, Bidin. ${ }^{10}$ Bidin is a son of Ren Tasim, who is a son of Senang Irah.

\section{Figure 2: Genealogy of two Jungkuk of Tanjung Karangan village}

1 Puyang Pageran
2 Puyang Jalil
3 Senang Irah
4 Setiarap
5 Limat
6 Resek
7 Lamit
8 Ren Tasim
9 Dahlan
10 Sari
11 Bidin

Note: The succession order of Jurai Tue is indicated in brackets and black.

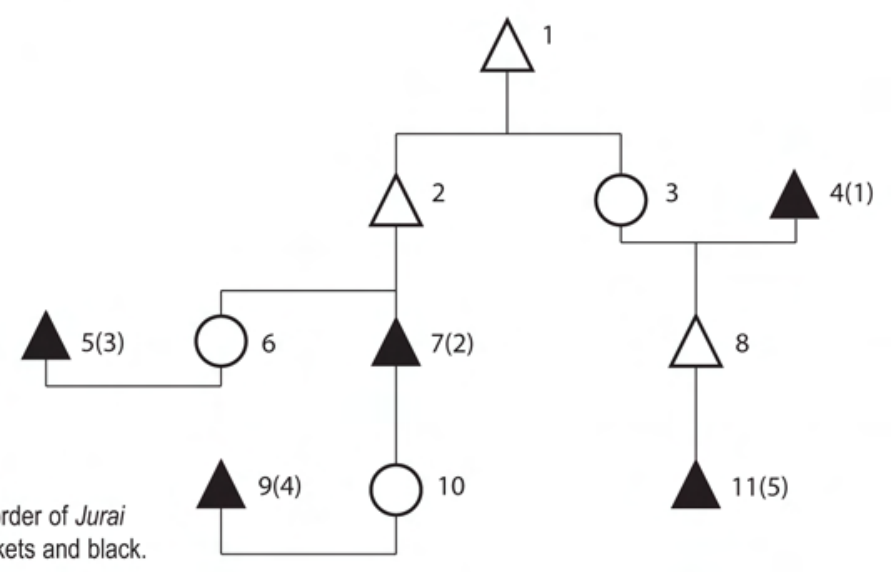

\section{The Division of a Village}

While the jungkuk is a subgroup within a village, which maintains its relations with the Puyang Ketunggalan Dusun, it can also become a point of division at the time of the establishment of a new village. The following example of the bifurcation of Mandi Angin village and the creation of Batay village will illustrate this process. 
Initially the name of Mandi Angin was Cugong Berangin and it was located at Muara Ayer Batay when it was founded by the founding ancestor, Kerie Tingal. Relocation of the site of this village took place several times and its name was changed to Cugong Keramai and eventually to Mandi Angin. When Mandi Angin village was relocated in 1925, it split into two parts. Some jungkuk members of Raje Ringkeh, Tue Jurai, created talang or a temporary residence near their gardens. It was named Talang Batay. The rest of the village moved to a new location and was named Mandi Angin village. When the Japanese army came to Lahat in 1942, Talang Batay was asked to move to a site along the Kikim Raya road. Since new Mandi Angin village was not spacious enough to accommodate the residents of Talang Batay, the residents bought some of the rubber garden areas of Tanjung Beringin and converted them into a village. Since 1944, this new village is known as Batay village. One person from the jungkuk of Raje Ringkeh who lives in Batay now assumes the role of the Jurai Tue in Batay village.

The jungkuk is a good example of what Fox $(1988,1996$ a) calls an origin group. Origin groups share and celebrate some form of common derivation including a common ancestor, a common cult and a collection of regalia (Fox 1996a: 132). The morpheme $p u$ in the word puyang could be a reflex of puqun, which is a Proto-Malayo-Polynesian reconstruction meaning tree, trunk, base or source (Fox 1995: 36). Yang, in turn, may be related to words such as eyang (Java), meaning grandparent, or hyang (Bali), meaning ancestor/deity. As a subgroup within a village, each jungkuk traces a chain of linkages to the village founder as source. Jungkuk are not 'lineages' in the classical sense because the succession of the Jungkuk titleholder is neither patrilineal nor matrilineal, but is comprised of any descendants as long as they continue to reside within the village of origin.

\section{Multiple Village Origins and Subgroups}

Most Gumai villagers can trace genealogical or affinal relations to the Puyang Ketunggalan Dusun. In the past, those who did not have genealogical connections to the Puyang Ketunggalan Dusun were allowed to reside in a village by forming a separate subgroup (sungut jurai) apart from the village's jungkuk groups. ${ }^{11}$

It is said that it was common to have sungut jurai composed of Semidang descendants. Based on the origin narratives in which Diwe Gumai and Diwe Semidang cooperated with each other to let Diwe Gumai emerge from the shell of a fruit on the Bukit Siguntang, descendants of Diwe Semidang were asked to be members of Gumai villages. Despite the explanations by the Jurai Tue and other elders about the existence of sungut, I was not able to identify who formed the sungut of the Semidang in any Gumai village. This is partially because the status of those who were initially accommodated as strangers and allowed to 
form a subgroup is not differentiated after three generations of continuous residence in that locality. ${ }^{12}$ Furthermore, younger generations, in general, do not pay much attention to the sungut or jungkut, and the transmission of knowledge related to village origins is difficult to discover. ${ }^{13}$

A person who still claimed foreign descent and was able to tell me an account of his foreign origin was the Mimbar of Mandi Angin village, Pak Amat Solek. Mimbar is another village ritual specialist who, in times of crises, must support and protect the Jurai Kebali'an. Solek owns coffee gardens near Pagaralam and looks after them diligently, and is a relatively wealthy coffee farmer residing in Mandi Angin village. In 1995, he told me the following story, which explains how his ancestor was accepted in Mandi Angin village:

Siatong Ali was a descendant of Bengkulu, who was at that time living in Rebakau. He held a wedding reception for his child and invited Puyang Gune Raje and his son, Kerie Tingal, went as his father's representative. At the wedding ceremony, Kerie Tingal was not offered food, rather he was ridiculed. So he went home and reported this incident to his father. Gune Raje then advised Kerie Tingal to return to the reception and to carry a dagger named Santan Tekuku with him and advised him to kill all the people with the dagger if he was ridiculed again. Kerie Tingal returned to Rebakau, and Siatong Ali noticed the dagger and asked its name. Upon learning that the dagger called Santan Tekuku was named after a bird, Siatong Ali said, 'So we shall give your bird some food.' 14 This time Kerie Tingal killed all the guests and all the inhabitants of the Rebakau with the dagger. After this incident, Siatong Ali and Kerie Tingal compromised and the former offered his daughter as evidence of submission. She became a wife of Gune Raje and gave birth to a son called Sialam. The family of Siatong Ali was allowed to live in Mandi Angin village as Mimbar of Mandi Angin village, whose duty is to fight at the front line in a war and help the five grandchildren of the Jurai Kebali'an in Mandi Angin village. Siatong Ali made a vow that he and his descendants would accept this duty and the title of Mimbar was inherited by his son, Puyang Demang. Sialam is believed not to be dead, but to have ever-lasting life in the mountain. He said, 'My children, if you are facing difficulty, just burn benzoin resin and bring a goat and call me.' Usually those who ask for assistance are able to achieve their wishes.

The narratives explain that the descendants of Siatong Ali did not share a common ancestry with the rest of the jungkuk members in Mandi Angin, who were descendants of Puyang Kerie Tingal. Siatong Ali was a stranger accepted into Mandi Angin village. Since he was trusted by Gune Raje, the title of Mimbar 
was given to Siatong Ali and has been inherited by one of his descendants ever since (see Figure 3). 15

Figure 3: Genealogy of the origin of the Mimbar of Mandi Angin village

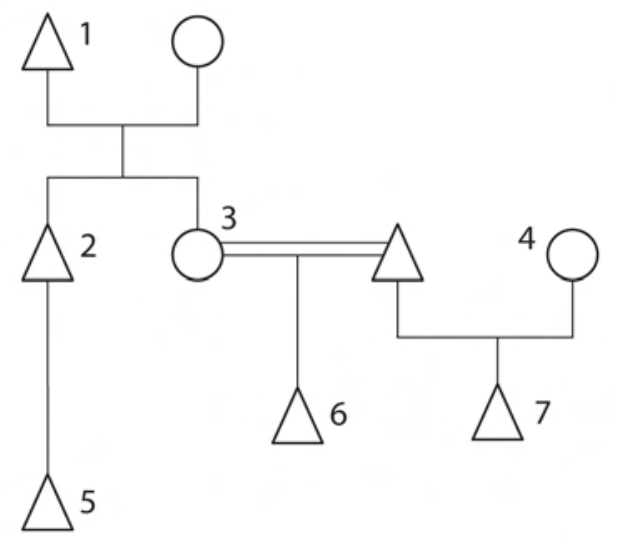

1 Siatong Ali

2 Demang

3 Putri Ratu Rebakau

4 Puyang Gune Raje

5 Ahmad Soleh, Mimbar of Mandi Angin

6 Sialam

7 Puyang Kerie Tingal (Puyang

Ketunggalan Dusun of Mandi Angin)

\section{The Merging of Two Villages}

Some villages in Gumai Talang were created by more than two founding ancestors who had no genealogical connections or whose genealogical connections were not known or remembered. For instance, Tanjung Baru village has three Jurai Tue, a result of acknowledging three village founders. However, details about how the three ancestors collaborated in establishing one village were not known to any of the current Jurai Tue.

Sugih Waras village has two Jurai Tue, Jurai Tue palak tanah and Jurai Tue ujung tanjung. The latter, Pak Zainal Kisam, a driver in his fifties operating in Lahat, was able to give me an explanation. ${ }^{16}$ Consulting some notes he had kept to refresh his memory, he explained to me that the current Sugih Waras village was a result of two villages that had merged into one.

Puyang Kebah, whose ancestry was traced back to an ancestor in Gumai Ulu, had three sons, Pati Kelam, Pati Tua and Pate Langit. Pati Kelam, the eldest son, was given the title of Jurai Tue. At that time, they were living in a place called Talang Kapuk along the Kikim Kecik River. But there never was peace in this village. Fighting among the villagers was a regular feature. So the Jurai Tue of Talang Kapuk, Puyang Pati Kelam, consulted Puyang Tuan Raje, the Jurai Kebali'an, who advised that Puyang Pati Kelam should ask a descendant of Puyang Pangeran Raje Depati in Lubuk Sele village, in Gumai Ulu, to establish a new village together.

Puyang Raje Depati was the Jurai Tue in Lubuk Sele village, who had two sons, Mas Agung and Kebile Agung. Mas Agung succeeded to the 
office of the Jurai Tue. This office was then inherited by his son, Cahaya Raden, and by his grandson, Puyang Tudakan Dalam. When Puyang Pati Kelam came to Lubuk Sele village, the Jurai Tue was Puyang Jikmat, who was a son of Tudakan Dalam. Upon consultation, Puyang Jikmat agreed to establish a new village in Tanah Kemiling with Puyang Pati Kelam. After establishing the new village in Tanah Kemiling, Puyang Pati Kelam, Jurai Tue of Talang Kapuk, became the Jurai Tue palak tanah and Puyang Jikmat became the Jurai Tue ujung tanjung in order to represent each origin. Palak tanah literally means 'the top of the land' and refers to 'upstream', while ujung tanjung literally means 'the tip of a cape' and refers to 'downstream'. Since then, Tanah Kemiling has become prosperous and peaceful. When this village was moved to another location, both Jurai Tue held discussions and created a new name, Sugih Waras. In the local language, sugih means rich and abundant, and waras is healthy. As this name suggests, residents of Sugih Waras village were rich and healthy by that time. After World War II, Sugih Waras village was moved again to its present location.

\section{Figure 4: Genealogy of Sugih Waras village}

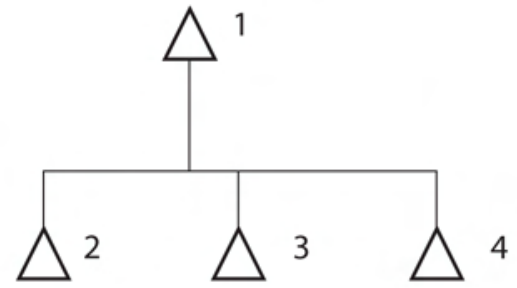

1 Puyang Kebah

2 Puyang Pati Kelam, eldest son, (Jurai Tue palak tanah)

3 Puyang Pati Tua

4 Puyang Pati Langit

5 Puyang Raja Depati,

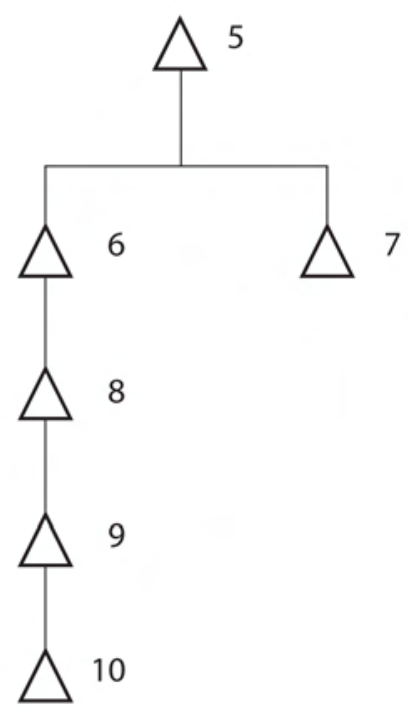

6 Puyang Mas Agung

7 Puyang Kebile Agung

8 Puyang Cahaya Raden

9 Puyang Tudakan Dalam

10 Puyang Jikmat, (Jurai Tue ujung

tanjung) 
Until the present, Sugih Waras village has retained two Jurai Tue, to represent the two founding ancestors, each of whom is replaced from within his own jungkuk line. Despite the ritual titles, there is no spatial division for residence among the descendants of the two jungkuk within the village. The existence of their two Jurai Tue illustrates that descendants of Sugih Waras village remember the two ancestors, Puyang Jikmat and Puyang Pati Kelam, as village founders, each represented by a Jurai Tue.

\section{Continuity of Person}

\section{Marriage Contracts and Residential Rules}

Until early this century, as in many regions of the South Sumatran highlands, villages in Gumai Talang did not accept strangers unless they were officially accepted as a subgroup or as in-laws. Two modes of marriage contracts, jujur (belaki, kule) and tambi anak (ambil anak), operated to regulate the residence of conjugal couples and contributed to maintaining exclusive village membership. 17

Jujur or belaki was a virilocal marriage that involved the payment of bride wealth. Belaki literally means 'to have or follow a husband' (laki). The bridegroom had to pay a sum of money to the father of the bride as bride wealth to formalise his marriage. In return for this payment, the tie between the wife and her native village was severed and she moved into the village of her husband. All the children she bore were then regarded as descendants of the husband's side. In other words, children regarded themselves as descendants of the village founder on their father's side, and regarded their natal village as asal or an 'origin place'. The payment of bride wealth meant the purchase (kule) of the wife's reproductive capacity. If she was widowed, she was not allowed to return home, and was expected to remarry a brother of her deceased husband; a practice known as nungkat.

Tambi anak is an uxorilocal marriage, which does not include the payment of bride wealth. In other regions of South Sumatra, such as among the Rejang and the Besemah, this mode of marriage was called ambil (ambel) anak or 'to take a child'. Due to the absence of bride wealth payments, the status of the husband was low and he became a member of the wife's family and had to sever ties with his native village. The children the wife bore were regarded as descendants of the wife's side. Children therefore regarded themselves as descendants of the village founder on their mother's side, and regarded their natal village as their origin place. Marriage between the same village members was said to have been by tambi anak marriage form. ${ }^{18}$

Marriage was not always between Gumai. Marrying a non-Gumai affected the status of children. In the past, all the people who were children of a conjugal union between two Gumai were differentiated from the children with one 
non-Gumai parent, who were known as jurai muda ('young descendants') and ranked lower than those born from Gumai parents. The descendants of non-Gumai couples who resided in a village were called anak tawan ("children of the captured') and ranked lowest in the village origin structure. ${ }^{19}$ After three generations of continuous residence, descendants of anak tawan or jurai muda were given equal status to those born of Gumai parents. ${ }^{20}$

Through the practice of jujur and tambi anak marriages, Gumai villages remained groups with largely shared genealogical and affinal relations, with a single founding ancestor or multiple founding ancestors. The Dutch and British authorities, however, believed that these two modes of marriage deprived individuals of their freedom, were humiliating and degrading and equated them with slavery. ${ }^{21}$ Supposedly when reformist Islamic movements reached the South Sumatran highlands, the penetration of Islamic marriage commonly known as nikah gradually replaced Gumai traditional marriage rules.

Islam taught that marriage should be a bond between a wife and a husband, and did not support the custom of nungkat. Along with this change, the selection of a spouse came to be regarded as a personal choice. Relations with the families of both parents should be maintained equally, and a couple should be free to choose a location for their new residence. According to the memories of elderly people in Gumai Talang, a meeting was held among the Gumai in 1944 to decide to abolish jujur and tambi anak marriages, and to replace them with tambi anak jurai sesame marriage. ${ }^{22}$ As its name suggests, this new form of marriage is similar to tambi anak marriage as it results in uxorilocal residence and has no bride-wealth payment. A husband may live with his wife's family but may leave the house of the wife's father after the couple construct their own. The difference is that this marriage form ensures bilateral relations with parents-in-law after marriage and that descendants are recognised as belonging equally to both the husband's and wife's group of origin.

Marriage is now regarded as a personal arrangement between two people, and nungkat is not usually practised or expected to take place any more. ${ }^{23}$ Table 1 shows that 67 percent of marriages that took place in villages in Gumai Talang during the period between 1994 and 1995 were uxorilocal. The three cases of neo-local marriage involved couples who moved from Gumai Talang villages to Jakarta or Palembang in relation to their work.

Table 2.1. Residential patterns of newly married couples in Gumai Talang between 1994 and 1995 (\%)

\begin{tabular}{lllll}
\hline Types of marriage & Virilocal marriage & Uxorilocal marriage & Neo-local marriage & Total \\
\hline Marriage cases & 16 & 38 & 3 & 57 \\
Per cent (\%) & 28 & 67 & 5 & 100 \\
\hline
\end{tabular}

Source: Marriages which took place between the period of 1994 and 1995 surveyed during fieldwork. 
With the prevalence of jurai sesame marriage, old terms related to the previous marriage systems have begun to be used with new meanings. Tambi anak and belaki now indicate post-marital residence patterns: the former refers to uxorilocal marriage and the latter to virilocal residential arrangements. ${ }^{24}$ Marriage contracts determine the status of descendants and restrict village membership to those who can trace their origins to village founders through genealogical or affinal relations.

\section{Petunggu Dusun}

The Gumai mention the name of their natal village to indicate their place of origin. The natal village is called dusun laman. ${ }^{25}$ The house in which one is born is regarded as an important place that connects the individual to a native village. Therefore, one member of the family is expected to inherit the family house to live in. The person who inherits the house is called petunggu dusun, which literally means 'the one who waits in the village'. This person is expected to reside in the house and to have his/her own descendants maintain and represent genealogical connections to the founding ancestor of their village. ${ }^{26}$ Gumai ritual specialists, Jurai Tue, Mimbar and Jurai Kebali'an, are all appointed as petunggu dusun among their family members and are asked to stay in their dusun laman.

Under the custom of the petunggu dusun, the village members consist largely of the households of petunggu dusun, who are regarded as the legitimate successors to their ancestors. In ritual language, ${ }^{27}$ which is used to invoke ancestral spirits, the residents of a village who are mostly petunggu dusun are referred to as bilang gagang jurai bilang batang nyawe ('each stem of a descendant, each trunk of a soul'). The petunggu dusun is the group who reproduces the next generation of the Gumai. In other words, each petunggu dusun is the trunk of life that derives from the ancestors as source and becomes an origin point from which the next generation of descendants is created. ${ }^{28}$

Leaving a house without an occupant in a natal village means losing connections with one's natal village as the point of origin. This is explained as lupe asal or 'forgetting origins'. Ancestral spirits are benevolent and will help their descendants to achieve their goals in life if they are remembered properly. Having derived from their ancestors, Gumai should not forget their ancestral origins. Forgetting one's origins can enrage ancestral spirits who can cause a series of misfortunes. Not having a petunggu dusun could make a member of a household mentally ill.

Except for the child appointed as petunggu dusun, the other children are free to live elsewhere. More than 50 percent of the parents in Gumai Talang surveyed during my fieldwork encouraged their children to leave the village to make their living. Yet, these emigrants should not forget their native village and should 
pay regular visits to their dusun laman with their spouses and descendants. At the time of their visit, the petunggu dusun should accommodate the returning siblings at his/her house and offer a place to hold a gathering. ${ }^{29}$

\section{Continuity of Place}

Despite a series of village relocations over time, each village retains some physical continuity to the old village sites that are associated with village founders. When a Gumai village needs to be relocated, members of that village cannot simply take up residency in any existing village due to the restrictive residential rules. This requires the Gumai to create a new village at a new site. At present, due to the shortage of land, a village relocation rarely takes place, yet in the past, a series of relocations took place. At these times, it was common to create a new village with village members at a new site, or to create a new village with other Gumai from a different village, or to split into two villages. In any case, having a physical link to the old site is essential for a new village site. No village has been relocated in the past 40 years, but an outline given by the Jurai Tue of Mandi Angin highlights the association between old and new village sites:

The Jurai Tue needs to carry a handful of soil from the old site and plant it in the centre of a new village site, where a lunjuk or balai desa was formerly built. In addition to the soil, a coconut tree and an areca nut tree need to be moved from the old site to the new site. These are also to be planted in the centre of the new village. Village ancestral spirits are to be informed of this relocation through the burning of benzoin and the presentation of offerings which include a goat as a sacrificial animal. 30

Through the replanting of trees and soil by the most authentic living descendants of the village, the Jurai Tue, the new site of a village is connected physically to the old village site.

\section{Lunjuk, Balai Desa and Mosque}

In the past, many villages in the South Sumatran highlands contained a small house that was a venue for the reverence of ancestral spirits (arwah puyang) and for performing a series of rituals commemorating village origins. These houses were known as lunjuk or rumah puyang (ancestors' house), and were constructed in the centre of a village, which was linked symbolically to the old sites. ${ }^{31}$ In Gumai villages, they are known commonly as lunjuk. ${ }^{32}$ The Jurai Tue of Mandi Angin told me the following story of why such a house was called rumah puyang.

Along the Lematang River, there existed five villages whose ancestry could be traced back to the king of Majapahit in Java (Ratu Majapahit). Because of this ancestry, Dita, Muara Siban, Selawi, Pagar Batu and Muara Temiang villages are known as Suku Lima (the five tribes), and 
are differentiated from the Gumai. ${ }^{33}$ The Gumai established affinal relations with them by marrying a younger sister of Gune Raje, a daughter of Remanjang Sakti, to the eldest son of Ratu Majapahit, Kerie Tabing. However, Kerie Tabing and Kerie Tungkal Diwe, a younger brother of Gune Raje, did not get along well and eventually Kerie Tungkal Diwe was murdered by Kerie Tabing. Gune Raje and his brother Pegeh (Bigeh) went to see Ratu Majapahit and demanded his son be punished for the death of Kerie Tungkal Diwe. Ratu Majapahit answered that he would surrender his son if Gune Raje and Bigeh successfully defeated Sunda Kelam, which was a part of Majapahit. Sunda Kelam is a territory which was sometimes visible and sometimes invisible, thus it is difficult to fight with. Gune Raje and Bigeh arrived at the site of Sunda Kelam but were unable to see anyone in the country. Therefore, they had to return home in vain. Remanjang Sakti ordered that another son of his, Betelak, should accompany the other two sons for this expedition to Sunda Kelam. Betelak was a great coward and he was not willing to come along. So it was suggested that his soul (nyawe) should be kept in a bamboo cigarette container called telak so that he would not feel timid or scared. When the three arrived in Sunda Kelam, Betelak performed solat twice. After his bowing, the heads of the residents of Sunda Kelam became visible; it looked as if the people of Sunda Kelam were floating in the sky. When Gune Raje prayed, the kingdom of Sunda Kelam then fell to the ground. The three Gumai men easily defeated Sunda Kelam. Gune Raje and his two brothers demanded evidence of their victory from Sunda Kelam and they were provided with two princesses and heirlooms. One of the two princesses was a daughter of Ratu Majapahit called Putri Dimengkute, and the other was a fairy (dayang) called Putri Kedayang. It was later decided that the two princesses would marry Gune Raje. Their heirlooms consisted of a cannon called Guruh Kemarau, a betel nut box called Bun, a gong known as Gong Pamor Sunda, and a dagger called Betak Sepamah. ${ }^{34}$ They took a boat and went up the Musi River. During their voyage, the marriage between the two princesses and Gune Raje took place. When they arrived at the Lematang River, Putri Dimengkute said, 'I cannot continue this journey since I cannot drink dirty water. So I shall return home.' Then she explained the secrets of the heirlooms: Bun needs to be washed in the river for a rain-making ritual. When the Guruh Kemarau roars, it is a sign that misfortune such as cholera is approaching. So a ritual to ward off the coming misfortune needs to be undertaken. Then she asked that all the heirlooms should safely be brought back to the place of Gune Raje. Putri Dimengkute then added that she wished to have a small house constructed in each Gumai village so that she could visit her descendants. This house was called lunjuk and 
was usually built in the middle of a village and used as a site of rituals to ward off misfortune.

The penetration of Reformist Islam into the interior led to the disappearance of lunjuk in the 1930s. Hoop (1932), who travelled around the South Sumatran highlands in the 1930s to investigate megalithic remains, photographed lunjuk located in Karang Dalam village of Gumai Lembak, currently located in the Pulau Pinang Subdistrict of the Lahat District. His comments show that Islam was then rapidly penetrating the highlands and replacing traditional customs.

In the middle of the doesoen stands a small spirits-house, 'roema dewa' or 'roema pojang' [sic], of the kind formerly found in all doesoens, but which are now disappearing rapidly under the influence of Islam. 35 (Hoop 1932: 13)

This lunjuk remains at the site as an example of local cultural heritage, but it no longer functions as a ritual venue. I was able to visit this lunjuk with the Mimbar of Karang Dalam village during my fieldwork. It was a small house made of wood, with a zinc roof placed on top of four wooden pillars, each of which were two metres high. The house was big enough for two to three people to sit in after they had climbed up a ladder to enter. Inside the lunjuk was empty space with only a mosquito net, which was rolled and placed on the floor. I was told that the Jurai Tue and Mimbar used to go inside the lunjuk at times of Sedekah Rame to burn benzoin and invoke ancestral spirits there.

After the demolition of lunjuk in many villages in the 1930s, balai desa were constructed on the same sites to cater for the needs of village meetings and Sedekah Rame. Balai desa consisted of a small room with a roof, and two long benches, both of which were made of bamboo. The room was a place for the Jurai Tue, Mimbar and the head of a village (Rie Punggawa) to sit, and was set half a metre higher than the benches. Each of the long benches was able to accommodate 40 people.

The balai desa in Mandi Angin village is said to have been demolished in 1944, when the Japanese Army organised a party and criticised the practice of differentiating seating and offering arrangements depending on status. Balai desa in other villages were also gradually demolished and replaced by village mosques along with the continuing Islamisation. In Mandi Angin, the village mosque stands on the old site of the balai desa and is vaguely associated in the minds of the villagers with the old site of their balai desa. There is a stone next to the village mosque called Tapak Puyang Dimengkute, which indicates the remains of the lunjuk at that site. Since the demolition of lunjuk and balai desa, the ritual venue of Sedekah Rame has been moved to the house of the Jurai Tue or to the newly constructed village mosque. There remains little in the layout 
of the current village that might provide a clue to Gumai belief in ancestral and natural spirits.

\section{Graveyard}

Not only does a village in Gumai Talang consist of the living who share their ancestry, it comprises the ancestral spirits. Thus a graveyard (kuburan) is considered an essential part of a Gumai village. The significance of a graveyard as part of a village was expressed in the following incident, which occurred during my fieldwork:

In August 1995, students of the University of Sriwijaya came as a part of Kuliah Kerja Nyata (KKN) and stayed in five villages in Gumai Talang for two months. KKN is a social project whose aim is to send the highly educated university students to underdeveloped areas of Indonesia where they are expected to learn from their rural experience. In this case, the students organised village seminars about nutrition and how to purify drinking water. Before they leave, it is customary for students to produce something as a souvenir of their stay. In Endikat Ilir village, some students prepared house number plates which showed addresses within the village, and distributed one to each household for display. 36 Students also decided to produce a souvenir by erecting two posts to show the boundaries of the village. Students consulted with the village heads of Endikat Ilir and Muara Tandi regarding the boundaries. One post was placed between Endikat Ilir and Mandi Angin, and the other was placed between Endikat Ilir and Muara Tandi along the Kikim Raya Road. The post which demarcated Endikat Ilir village from Muara Tandi village was placed at a site which did not include the graveyard of Endikat Ilir village. It was located behind the first house in Muara Tandi village through a lane from Kikim Raya Road. According to the view of the village head of Muara Tandi, the graveyard of Endikat belonged to Muara Tandi village and the space was only lent to Endikat Ilir village. From the point of view of legal status, the graveyard of Endikat Ilir village was located within Muara Tandi village. The village head of Muara Tandi therefore asked the students to put the post so that it excluded the graveyard from Endikat Ilir village. Soon after this post was placed, the Jurai Kebali'an asked the village head of the Muara Tandi village to relocate it so that the lane to the graveyard should be regarded as a part of Endikat Ilir village. He explained that even though the graveyard is officially located within the territory of Muara Tandi village, those buried in the graveyard are all from Endikat Ilir village, including the previous Jurai Kebali'an. If the graveyard is not considered to be a part of Endikat Ilir village, the village does not have a graveyard and the deceased members of the village would be buried in Muara Tandi 
village. The Jurai Kebali'an insisted that the boundaries of Endikat Ilir village should include the village and its own graveyard, and this was approved by the village head of Muara Tandi. After this negotiation, the post was moved to a location which showed that the lane as well as the graveyard could be regarded as a part of Endikat Ilir territory.

In the past, each jungkuk and sungut had its own burial site. Due to a series of relocations and a shortage of land, however, many Gumai villages now have a single graveyard. Even when a village member dies outside South Sumatra, it is common to transfer the body of the deceased person to his/her village graveyard. The previous Jurai Kebali'an passed away in Jakarta in 1999 and his body was taken back to Endikat Ilir village to be buried. This is despite the fact that, according to Islamic teaching, a body should be buried as soon as possible.

Each village in Gumai Talang has its own graveyard. An exception is the graveyard shared by Suka Rame and Tanjung Dalam villages. Since the founding ancestors of the two villages were brothers, villagers regard the two villages as one unit and find no problem in sharing a common graveyard. ${ }^{37}$ All the villagers who were born and raised in a village expect to be buried in its graveyard, and access to burial in a village graveyard is restricted strictly to village members.

In a Gumai village graveyard, there are a series of mounds of earth or spots marked by circles of big stones which indicate burial sites. The mound is often decorated with flowers. Relatively wealthy people convert the mound of soil into a rectangular coffin made of ceramics or cement. A village graveyard is always associated with the spirits of the deceased, and people dare not go there alone at night. Spirits of the ancestors believed to reside in the graveyard can be seen at night.

Due to a series of village relocations from the original village site, village founders' graves are located in old village sites, and not in the current village graveyard. In a current village site, however, it is common to find a memorial place called tapak ('site') related to a village ancestor. A relatively new tapak exists in Tanjung Beringin village, which is believed to have been constructed in the 1940s. It takes the form of a rectangle, framed by stone and cement and raised 60 centimetres from the ground. It is approximately three metres wide and five metres long and has two poles, which are said to represent the head and the legs. This tapak is surrounded by a fence made of wood. The tapak was constructed because the old site of the ancestral grave had been chosen for a planned railway track. I was told that the spirit of the Puyang Ketunggalan Dusun was asked to move from the old site to the new site on the completion of the new tapak. Even though the body of the ancestor was not buried there, the spirit is believed to reside in the new site. Villagers occasionally visit this tapak, clearing grass and sprinkling water around it, particularly in the month of 
Ruwah. ${ }^{38}$ Some bring a set of offerings consisting of rice cakes and betel nuts, and recite Yasin, the 36th surah of the Qur'an.

Despite its geographical detachment from the village settlement, the graveyard of each village constitutes an extension of a Gumai village, which consists of the living and the dead. A Gumai village is an entity of linkages to village origins represented by the descendants and important sites.

\section{The Marga System and its Impact}

Let me finally examine the impact of an external administrative unit, the marga system, on the succession and continuity of a Gumai village. The marga system was used originally by the Sultanate of Palembang, and then was made into a rigid administrative unit by the Dutch Administration in the highlands of South Sumatra in the 19th century.

In order to rule indirectly in an efficient manner, the Dutch concentrated administrative power in a single person, the head of a marga, a territorial unit, and appointed him as pasirah (Galizia 1996: 136-8). A pasirah was a representative of the people of a marga and important decisions were always made through discussions among elders within his marga unit. In contrast, the Dutch-appointed pasirah was made to assume the role of the centralised ruler of a marga, with more power in his hands. Only his family members were allowed opportunities for Western education, which provided close connections with the Dutch Colonial Government. ${ }^{39}$ A marga, in turn, consisted of several villages (dusun), each of which was headed by a local Proatin with the title of Krie, Lurah or Ginda. Through this indirect control and manipulation of their power at the marga level, the Dutch succeeded in directing their administrative power into the lower levels of political organisation in the highlands. 40

A consequence of the implementation of the marga system was that, by 1930 , the Gumai were divided into several marga located in various parts of Southern Sumatra. According to Wellan's report (1932: 194-8), Marga Gumai Talang and Marga Gumai Lembak were located in Lematang Ulu Subdistrict, while Gumai Ulu and Pagar Gunung were located in the Pasemahlanden Subdistrict. These four marga were located in the Palembang Highlands. Other marga in which the Gumai were the main population group included Marga Rambang Ampatsuku in the Ogan Ilir Subdistrict, and two marga in the Bengkulu Residency: Marga Anak Gumai in the Manna Subdistrict and Marga Semidang Gumai in the Kaur Subdistrict.

In this process of institutionalising the marga system, non-Gumai villages were also incorporated into Gumai marga. For instance, the people of Jati village in Marga Gumai Lembak claim descent from Suku Lima, who were descendants of the legendary Javanese Kingdom of Majapahit, but Jati village became a part of Marga Gumai Lembak. The creation of Marga Semidang Gumai in South 
Bengkulu was the result of combining Gumai villages and Semidang villages into one marga.

The marga and pasirah system continued after the independence of Indonesia until the implementation of the Law on Village Administration No. 5 of 1979 (Undang-Undang 5/1979) under which each marga was divided into various villages known as desa.

Despite the implementation of the marga system, the aim of which was primarily for administration by the outer authorities, it did little to interfere with the social structure and ritual practice of each village. For example, the Gumai did not consider marga as a unit sharing origins nor did they develop rituals for the marga. Marga was perceived as a unit of political administration and knowledge about each village was transmitted by a ritual specialist from each village. There were some discussions on the revival of the marga system as a result of regional autonomy in 2000-01, but the idea did not gain any political momentum.

\section{Conclusion}

I have examined origin structures and the related roles of ritual specialists among the Gumai of South Sumatra. I have noted that a majority of Gumai villages have to date maintained their distinctive nature as territorial units and maintain a range of rituals to commemorate the origins of their villages. As I have described elsewhere (Sakai 1999, 2002, 2003), they also undertake rituals commemorating their family origins and the origin of the founding ancestor through a monthly ritual, despite the penetrating influence of Islam.

This does not mean Gumai tradition has remained intact and free from challenges. Outside the three settlements of the Gumai there are in fact many villages where a large number of newcomers have settled, which is blurring the definition of village membership. In the case of the neighbouring Besemah people, the influence of reformist Islam has been such that rituals associated with origins have been abandoned. Along with the abandoning of knowledge and rituals, definitions of village membership are no longer as restricted and outsiders are increasingly accepted. Other challenges arise from the migration of younger residents to big cities such as Palembang and Jakarta, which can leave their villages depopulated. People can no longer guarantee a member of the family to serve as petunggu dusun. A critical situation arises when there is no one who is prepared to reside in a designated village and act as the Jurai Tue or even the Jurai Kebali'an. Knowledge about the origins of the Gumai is no longer considered particularly important by many younger Gumai. Since the death of the previous Jurai Kebali'an in November 1999, the successor to the office has not been properly appointed. An elder brother of the deceased is assuming a role 
temporarily. Whether this is merely an example of traditional menyandung or another indication of a demise of Gumai tradition remains to be seen.

\section{References}

Andaya, Barbara Watson. 1993. To Live As Brothers: Southeast Sumatra in the seventeenth and eighteenth century. Honolulu: University of Hawai'i Press.

Bellwood, Peter. 1996. 'Hierarchy, founder ideology and Austronesian expansion.' In J.J. Fox and C. Sather (eds), Origins, Ancestry and Alliance: Explorations in Austronesian ethnography, Canberra: Department of Anthropology, Research School of Pacific and Asian Studies, The Australian National University.

Collins, William. 1979. 'Besemah Concepts: A study of the culture of a people of South Sumatra.' Unpublished PhD Thesis, University of California, Berkeley.

Collins, William. 1998. The Guritan of Radin Suane: A study of the Besemah oral epic from south Sumatra. Leiden: KITLV Press.

Encyclopaedie van Nederlandsch-Indië 1919 (2nd edition). 's-Gravenhage: Martinus Nijhoff.

Fox, James J. 1971. 'Sister's child as plant: Metaphors in an idiom of consanguinity.' In R. Needham (ed.), Rethinking Kinship and Marriage, London: Tavistock. pp. 219-52.

Fox, James J. 1980a. 'Introduction.' In J.J. Fox (ed.), The Flow of Life: Essays on eastern Indonesia, Cambridge (Mass.): Harvard University Press. pp. 118.

Fox, James J. 1980b. 'Models and metaphors: Comparative research in eastern Indonesia.' In J.J. Fox (ed.), The Flow of Life: Essays on eastern Indonesia, Cambridge (Mass): Harvard University Press. pp. 327-33.

Fox, James J. 1988. 'Origin, descent and precedence in the study of Austronesian Societies.' Public lecture in connection with De Wisselleerstoel Indonesische Studien in Leiden, The Netherlands, March 17, 1988.

Fox, James J. 1995. 'Origin structures and systems of precedence in the comparative study of Austronesian societies.' In P.J.K. Li, Cheng-hwa Tsang, Ying-kuei Huang, Dah-an Ho and Chiu-yu Tseng (eds), Austronesian Studies Relating to Taiwan, Symposium Series of the Institute of History and Philology, Academia Sinica 3, Taipei: Academia Sinica. pp. 27-57.

Fox, James J. 1996a. 'The transformation of progenitor lines of origin: Patterns of precedence in eastern Indonesia.' In J.J. Fox and C. Sather (eds), Origins, Ancestry and Alliance: Explorations in Austronesian ethnography, Canberra: Department of Anthropology, Comparative Austronesian 
Project, Research School of Pacific and Asian Studies, The Australian National University. pp. 130-53.

Fox, James J. 1996b. 'Introduction.' pp. 1-17. In J.J. Fox and Clifford Sather (eds), Origin, Ancestry and Alliance: Explorations in Austronesian ethnography, Canberra: Department of Anthropology, Comparative Austronesian Studies Project, Research School of Pacific and Asian Studies, The Australian National University. pp. 1-17.

Galizia, M. 1995. Aufstieg und Fall der Pasirah: Zentralstaatliche Vereinnahmung und lokale Machtstrategien. Berlin: Reimer.

Galizia, M. 1996. 'Village institutions after the Law No. 5/1979 on village administration. The Case of Rejang-Lebong in South-Western Sumatra.' Archipel, 51. pp. 135-60.

Hayatuddin. 1992. Sumatra Selatan Propinsi Peleburan Suku Bangsa, Proyek I: Identitas dan Etnis di Sumatra Selatan. Palembang: Pusat Penelitian Universitas Sriwijaya.

van der Hoop, A.N. 1932. Megalithic Remains in South Sumatra. Zutphen: W.J. Thieme \& CIE.

Jaspan, M.A. 1976. 'Redjang complex.' In Frank LeBar (ed.), Insular Southeast Asia: Ethnographic studies, Vol. II, New Haven: Human Relations Area Files.

Lewis, E. Douglas 1996. 'Origin structures and precedence in the social orders of Tana 'Ai and Sikka.' In J.J. Fox and C. Sather (eds), Origins, Ancestry and Alliance: Explorations in Austronesian ethnography, Canberra: Department of Anthropology, Comparative Austronesian Studies Project, Research School of Pacific and Asian Studies, The Australian National University. pp. 154-74.

Marsden, William. 1986. Reprint of 3rd ed. The History of Sumatra. Singapore: Oxford University Press.

Sakai, Minako. 1997. 'Remembering Origins: Ancestors and Places in Gumai Society of South Sumatra, Indonesia.' In James J. Fox (ed.), The Poetic Power of Place: Comparative perspectives on Austronesian ideas of locality, Canberra: Department of Anthropology, Research School of Pacific and Asian Studies, The Australian National University. pp. 42-66.

Sakai, Minako. 2000. 'The Nut Cannot Forget Its Shell: Origin Rituals among the Gumai of South Sumatra.' Unpublished PhD thesis. The Australian National University: Canberra.

Sakai, Minako. 2002. 'Modernising Sacred Sites in South Sumatra? Islamisation of Gumai Ancestral Places.' In The Potent Dead, Anthony J.S. Reid and 
Henri Chambert Loir, (eds). ASAA series, Allen \& Unwin, University of Hawai'i Press. pp. 103-16.

\author{
Sakai, Minako. 2003. 'Publicising Rituals and Privatising Meanings.' In N. \\ Tannenbaum and C. Krammerer (eds), Founder's Cults: Ancestors, Polity \\ and Identity in Southeast Asia, Yale University Press. pp. 159-83.
}

Skeat, William. 1967 [1900]. Malay Magic. New York: Dover Publications, Inc.

Wellan, J.W.J. 1932. Economisch overzicht van de gewesten Djambi, Palembang, de Lampoengsche Districten en Benkoelen. Wageningen: H. Veenman \& Zonen.

\title{
ENDNOTES
}

1 Sometimes the title is known as pejungkuk, but in many cases people just used the word jungkuk to refer to the social unit and the title.

2 See Chapter Five of Sakai (2000) for rituals related to village origins.

3 The Gumai often comment on the Besemah, a neighbouring ethnic group, saying that the Besemah have severed their descendants (putus jurai). It does not mean that the Besemah have become extinct; in fact, the number of the Besemah population is far larger than that of the Gumai. Putus jurai refers to their view that the succession of legitimate descendants among the Besemah has been broken. Collins (1998: 487) translates it as 'to have one's line extinct'.

4 Lewis (1996: 155) provides a similar interpretation of older houses in Tana 'Ai of Flores. Older houses exert more social and ceremonial precedence due to their temporal proximity to the source.

${ }^{5}$ The manifestation of this precedence system is said to have been abolished in 1944 during the Japanese military occupation, which forbade differentiation of the people based on rank and encouraged cooperation among the villagers.

${ }^{6}$ Bellwood (1996: 24) states that 'high rank derived from genealogical closeness to an important founder would give access to the economic rights usually associated with chiefs.' However, the ranking of jungkuk does not involve any economic prerogatives.

7 As women are responsible for the organising of an elaborate set of offerings at times of rituals to commemorate origins, it is reasonable to allow a daughter to succeed to the title of Jurai Tue, and let her husband perform the role. Women were and still are not allowed to perform the role of the Jurai Tue.

8 Regalia include weapons such as kris and tombak. Some of the regalia were said to have been taken by the Dutch at the time of the Fort Jati War.

9 The reason for this transfer was not remembered. Ren Tasim, who was expected to assume this role, might have been too young to carry out the task.

10 I came to know some cases of disputes over the succession of the Jurai Tue. For an example of contestation of precedence see Sakai (2000, Chapter Five).

11 The residential rule still operates in the 14 villages in Gumai Talang but is no longer observed in villages located in the lowland area of South Sumatra.

12 After three generations, distinctions are no longer made. In fact, I did not encounter any person who claimed his or her origin from Diwe Semidang in villages in Gumai Talang during my fieldwork.

13 The Besemah consist of six subgroups called sumbai, but Hayatuddin (1992: 19) reports that the significance of the sumbai was so minimal that its meaning was not known to his Besemah informant.

14 Not offering food to guests is considered rude among the Gumai. The fact that Kerie Tingal was not offered food indicates that he was not treated as a guest.

15 The acceptance of Siatong Ali and his descendants is still remembered and their status as a part of the origins of Mandi Angin village is expressed at Sedekah Rame ceremonies in the village.

16 The Jurai Tue palak tanah, Pak Hasan Basri, had lived for a long time in Palembang and had hardly any knowledge about the village origins of Sugih Waras. 
17 One of the early references regarding the practice of these two modes of marriage is Marsden (1986: 225-9, 235-7), who described the two practices among the Rejang.

18 First-and second-cousin marriage was prohibited and still is strongly discouraged among the Gumai. This was because cousins share the same origin and relationships between them were considered incestuous. This made marriage among members of the same village rather difficult.

19 According to Collins (1998: 311), anak tawan were normally women and children who were captured from enemy villages among the Besemah or became captives due to debt. They were often kept as sex slaves. The Besemah are reluctant to talk about who are the descendants of these women.

20 All these classifications functioned until the middle of last century but no longer feature in the daily life of the Gumai.

21 For a summary of the Dutch view on South Sumatran marriage modes, see Collins (1979: 125-51).

22 Another name for this marriage is semendo, which became widely practised after the prohibition of jujur and ambil anak marriage (Collins 1979: 144-45).

23 Marriage arranged by parents was known as rasan tue, in contrast with the marriage decision made by a couple based on their romantic feelings (rasan mude). In the past, rasan tue was a common practice among the Besemah elites (Collins 1998: 19). Since rasan tue is no longer popular, an expression, ade rasan, is often used among the Gumai today when parents announce the engagement of their children. It means that there is a mutual agreement between a young man and a young woman to marry.

24 In daily conversations with Gumai men and women regarding the whereabouts of other family members, I often received these replies: 'Kerawai aku udem belaki' — My sister has taken a belaki marriage' or 'Jemetu, milu binie, ibarate sini tambi anak' — 'That person has followed his wife to live in his wife's village'. This practice is called tambi anak here.

${ }^{25}$ Dusun laman is an equivalent of the Indonesian term kampung halaman, 'birthplace' or 'natal village'. Laman means yard.

26 The person who is chosen as petunggu dusun normally inherits gardens too so that he or she can make a living from agriculture.

27 See Sakai (2000, Chapter Five), on the ritual language used by the Gumai.

28 Botanic metaphors of life are used widely among Austronesian speakers as a discourse on origin and as kinship terms. For linguistic analyses of metaphorical botanic expressions, see Fox (1971, 1980a, 1980b, 1996b).

29 For details of rituals related to individual origins, see Sakai (2000, Chapter Six).

30 Classifications of sacrificial animals are of great importance for the Gumai. The sacrificial goat for this occasion is kambing irang, which is a red-haired goat.

31 The Besemah, the Gumai and the Kikim are known to have possessed small houses for ancestral spirits. In addition to the lunjuk in Karang Dalam village that I have mentioned, there is another lunjuk located in Pagardin village of the Bunga Mas Subdistrict of the Lahat District. People say that this lunjuk glows in the dark on every 13th night according to the lunar calendar.

32 Among the Besemah this building was called rumah poyang (ancestors' house) and was replaced by a mosque (Collins 1979: 173).

33 These villages were administered as a part of Marga Gumai Lembak.

34 Guruh Kemarau was believed to have been taken to the Netherlands after the Fort Jati War. Skeat (1967:373) reports that bun in the Malay Peninsula refers to bun in Dutch, which means 'a large tin or copper box for tobacco or sirih leaves'. Among the Gumai, the pronunciation of bun is close to bon; the bon is kept in the house of the Jurai Tue in Mandi Angin village. Gong Pamor Sunda is kept at the house of the Jurai Tue of Lubuk Sepang. Betak Sepamah is located in the house of the Jurai Kebali'an.

35 Doesoen is an old spelling of dusun, a hamlet.

36 Residents in a village all know who lives where, and a mailman delivers all the mail to a stall along the road or the house of the village head, hence number plates in the village do not have any practical value in daily life.

37 They used to share a village mosque, but now each village has its own.

38 Another name of this month is Sya'ban. In this month, spirits of the dead are believed to return to their native places and people visit the graveyard.

39 Only the Pasirah was allowed to use stamps for documents to show his authority.

40 Local administrative officers such as pasirah, proatin and penggawa were nominated by people in the marga and then appointed by Dutch authority. The Dutch exerted influence and manipulated 
nominees in their favour. In order to represent the administrative hierarchy among native administrators, the Dutch granted distinctive titles such as Depati and Pangeran upon appointment, and demonstrated these titles by providing distinctive caps and buttons (Encyclopaedie van Nederlandsch Indië 1919: 267-8). Extensive marga were divided into smaller units to decrease their power, and a non-cooperative marga was joined with another marga, which was close to the Dutch authority. For a case study of the pasirah system in Bengkulu Residency, see Galizia (1995). 